\title{
The Causes of Anxiety in Highly Anxious Students in Japanese Communicative EFL Classes
}

\author{
Takako Inada ${ }^{1,2}$ \\ ${ }^{1}$ Department of Health Sciences, Japan University of Health Sciences, 1961-2 Satte, Satte-shi. Saitama 340-0113, \\ Japan \\ ${ }^{2}$ Department of International Communication, Kanda University of International Studies, 1-4-1, Wakaba, \\ Mihama-ku, Chiba-city, Chiba 261-0014, Japan \\ Correspondence: Takako Inada, Department of Health Sciences, Japan University of Health Sciences, 1961-2 \\ Satte, Satte-shi. Saitama 340-0113, Japan \& Department of International Communication, Kanda University of \\ International Studies, 1-4-1, Wakaba, Mihama-ku, Chiba-city, Chiba 261-0014, Japan.
}

Received: February 4, 2021

Accepted: January 7, 2022

Online Published: January 12, 2022

doi: 10.5539/elt.v15n2p1

URL: https://doi.org/10.5539/elt.v15n2p1

\begin{abstract}
The purpose of this study was to identify the causes of speaking anxiety in highly anxious students, of which their teachers might not have been aware, and solutions to alleviate the problem. Sixteen students from a Japanese language-oriented university participated in an interview survey. The participants' anxiety levels were measured using a five-point Likert scale questionnaire that included five items related to foreign language classroom anxiety. The results were compared to the results of interviews with their teachers, and interesting responses from the student interviews that their teachers did not raise were highlighted. The main causes of anxiety were an unpleasant classroom environment, peer pressure, and non-ideal class types. Students argued for several strategies to reduce the anxiety associated with speaking practice, increase their use of English, and improve their proficiency. To achieve these strategies, teachers need to take into account the opinions of students they did not previously focus on.
\end{abstract}

Keywords: foreign language classroom anxiety, highly anxious students, interview survey, Japanese university, communicative EFL classrooms

\section{Introduction}

It has been pointed out that students' emotions have a tremendous influence on the acquisition of English as a foreign language (EFL), but very few studies in the field of English education have focused on students' feelings of anxiety. The English-only policy, which severely restricts the use of the first language (L1), has been applied in many Japanese EFL communication classes with the aim of improving proficiency in the target language (TL), but the policy is one of the main causes of anxiety in these classes (Rivers, 2011). However, there may be other factors that make students feel uneasy and unwilling to speak English in class. Moreover, if teachers could address the anxiety of highly anxious students, this would have a positive effect but, if they are not able to do so, their students' anxiety will not decrease at all. Therefore, the ultimate goal of this study was to identify the causes of anxiety of which teachers were unaware and that prevent highly anxious students from practicing speaking English in the classroom, and to find solutions to mitigate the problem. Based on the findings, the pedagogical implications can be shared with teachers and suggestions can be given regarding how to create an environment that reduces the students' anxiety.

\section{Literature Review}

College English education in Japan has recently made strides in improving speaking skills by changing from a teacher-led instruction system to a student-centered language-learning system. In order to encourage students to participate actively in such lessons and ultimately to attain fluency when speaking in English, it is important to implement classes that take students' emotions into account. Horwitz, Horwitz, and Cope (1986) explained that foreign language classroom anxiety (FLCA) was distinct from other forms of anxiety, such as stage anxiety, test anxiety, and the like. FLCA arises due to fears and frustrations when even people who have no language 
disability cannot understand what foreigners say and cannot express what they want to say in a TL. Fenyvesi (2021) identified three categories of situations that make students anxious:

1) Students are afraid of making mistakes,

2) students are asked to speak in English in front of their peers and worry about being criticized or laughed at, and

3) students do not understand what the teacher says in the TL and cannot complete any of the tasks.

Students with high levels of anxiety may stop studying a TL completely due to a loss of motivation to study (Phillips, 1992). Students' anxiety should be kept at low levels in order to improve their speaking proficiency (Botes, Dewaele, \& Greiff, 2020). For example, the song instruction method has been found to reduce the average FLCA in a class of highly anxious students (Dolean, 2016).

Competitiveness with peers was one of the main causes of anxiety (Bailey, 1983), and students felt uncomfortable and anxious when they perceived a difference between their TL ability and that of their peers (Kang, 2005; Yan \& Horwitz, 2008). In particular, students who were less proficient in a TL were more anxious and tended to use their L1 more often (Ahmad \& Jusoff, 2009; Kim, 2011). To solve this problem, it has been proposed that students with low-level TL proficiency should improve their proficiency by practicing speaking the TL diligently both inside and outside of the classroom (Young, 1990). Similarly, anxiety was a strong negative predictor of overall willingness to communicate in the TL. Teachers could assign a variety of challenging but achievable tasks that involve the use of the TL in a variety of ways inside and outside of the classroom (Liu, 2017). However, it is better for students to take the initiative in all activities themselves (MacIntyre \& Doucette, 2010). Another solution is for students who speak a TL well to become student-teachers and to assist classmates who are less proficient in the TL (Murphey, Falout, Fukuda, \& Fukada, 2014).

Therefore, it is advisable that some appropriate actions should be taken to decrease students' anxiety (Horwitz, 2000; Zhang, 2019). According to Pan and Zhang (2021), teachers may be able to create mutual trust by building appropriate personal relationships with their students, and students can build a better trusting relationship with their classmates by improving their mutual trust, which will create a positive classroom environment. For example, a student-centered environment should be created (Jordan \& Gray, 2019), and teachers should encourage students to practice speaking in the TL (Najeeb, 2013) because students who are unwilling to communicate with their classmates may not progress as rapidly and may continue to experience higher levels of anxiety (MacIntyre, Noels, \& Clement, 1997). On the other hand, frequent TL use could decrease the students' anxiety when speaking and reduce their reliance on the L1 (Levine, 2003). Students feel anxious and embarrassed about making mistakes when they are speaking to the entire class; thus, pair/group work can help to reduce their anxiety (Gregersen, MacIntyre, \& Meza, 2014). Accordingly, the following research question was proposed: What are the causes of and solutions to speaking anxiety among students of which their teachers are unaware in EFL communication classes at a Japanese university?

\section{Methodology}

\subsection{Participants}

This was a mixed-method study: A quantitative survey was conducted to determine the levels of anxiety of the volunteer students, and a qualitative survey was conducted to identify the students' true feelings about their anxiety.

First, 37 volunteer students attending a private, foreign language-oriented university located in an urban area in Japan participated in a small-scale preliminary questionnaire survey. Since this was a preliminary survey for future research to learn more about the issues causing anxiety and to decide on which factors to focus, additional students were not recruited after having reached a satisfactory number. The university's population was approximately 2880 students in total, with about 720 students in each grade; around 450 students were majoring in English, about 120 in Spanish and Portuguese, and around 150 in Asian languages.

The five-item questionnaire regarding FLCA, which was devised by Saito and Samimi (1996) who adopted Gardner's (1985) FLCA scale (Cronbach's alpha $=0.89$ ), was used to measure students' anxiety in EFL classes (see the appendix). Students from different departments were asked to complete a questionnaire regarding their communicative English classes.

In the present study, the levels of anxiety of the students who answered the questionnaire ranged from 25 (the highest) to eight (the lowest), with 18 as the median. The Cronbach's alpha value was 0.758 , which showed that the five items had internal consistency. Based on the quantile distribution of $90-2.5 \%$ for anxiety, 16 students 
with an anxiety range of 25-22 were chosen as the high anxiety group. No significant differences in anxiety levels were observed in relation to gender $(p=0.076)$ or to the major subject (English or other languages) $(p=$ 0.185). The characteristics of the participants and the relationships between some variables and the anxiety levels assessed using the FLCA scale were analyzed using SPSS Statistics 23 (advanced version) with the statistical significance set at $\mathrm{p}<0.05$.

The 16 students with high anxiety (three males and 13 females) then participated in an interview survey. As the ratio of males to females was roughly the same ratio as in the entire university, it was not biased. The participating students were majoring in languages in the English Department (five students, four females and one male), the Chinese, Spanish and Korean (CSK) Department with Chinese (two females), Spanish (two females), and Korean (three females), and the Ibero-American Department with Portuguese (one male), Indonesian (one female), Thai (one female), and Vietnamese (one male). The students were aged between 18 and 21; five were freshmen, seven were sophomores, and four were juniors. The students' first language was Japanese, and almost all of them were of Japanese descent, though one was of mixed race (a Taiwanese mother and a Japanese father).

Interviews with six teachers who taught the participating students were also used in this research. For more information, see the article (Inada, 2021).

\subsection{Interviews}

During the individual interviews, the students with high levels of anxiety were asked for their actual opinions and experiences, as follows: Do you feel anxious when speaking English during communication class activities? If so, what makes you anxious, and what do you think would solve the problem? Following Mackey and Gass' (2008) advice, each individual interview (about 15 minutes) was conducted in Japanese to allow the participants to express their opinions clearly and to avoid communication problems due to limited English proficiency. During the interviews, the researcher (a Japanese-English bilingual whose native language is Japanese) took notes and audio recordings. The interviews were conducted in a quiet area of the campus at a time that suited the participants' schedules. For the statistical analysis, the responses to the interviews were transcribed, translated into English, and coded to make the data anonymous and to develop categories. Categorizations of coding were created based on the anxiety factors identified by previous researchers, such as a comfortable classroom environment (Murphey et al., 2014), peer pressure (Liu \& Jackson, 2008), and an effective class type (Wilkinson, 2012). Patterns and relationships in the interview data were identified and analyzed using QSR NVivo12 qualitative software. The teachers who taught the students who participated in this research were asked how they managed the students' anxiety during class in individual interviews (see Inada, 2021).

\section{Results}

The interview survey of the students revealed that the factors considered likely to increase their anxiety and to prevent them from speaking English willingly were an uncomfortable classroom atmosphere, peer pressure, and an inappropriate class type (there were two types of classes, a mixed-level class and a not mixed-level class). All 16 students said that they needed a comfortable classroom environment. Most of the students (15) confessed that they felt peer pressure to varying degrees. Opinions were divided with regard to the effective class type: Some students (11) said that it would be better to create a class that was divided into levels according to their speaking ability, while others (five students) said that it would be better to have a mixed class. The students' opinions provided some insights into the causes of anxiety and ideas for reducing anxiety.

In 2021, the author published an article that reported on interviews with teachers to discuss their strategies for decreasing their students' anxiety levels to improve their communication skills. The comments that were extracted from the teachers' interviews in the article were compared to those taken from the students' interviews in this study in order to obtain more interesting results. It was found that teachers and students had both similar and differing opinions. The similar opinions are discussed below.

To create a comfortable classroom environment, the teacher should use simple English to explain difficult aspects and grammar to the students. The students should be allowed to choose the topics they want to discuss freely, and to use both bilingual dictionaries and a few L1 terms when necessary. It would be preferable for pair/group work to increase and for each to group present simultaneously so that only the members of a group are listening to that group's presentation. It is also important for classmates to get to know each other in order to practice speaking English comfortably. With regard to peer pressure, poor speakers of English feel inferior and fear being ridiculed; thus, fluent speakers of English need to be more attentive and to teach less-proficient speakers useful English expressions instead of criticizing them when they use the L1. In terms of the effective class type, group dynamics are important in all classes because low-level students tend to start conversations in 
Japanese instead of in English in the absence of students with high levels of speaking ability. Table 1 shows the students' opinions of which the teachers were unaware.

Table 1. Interview Results: Interesting Comments

I can feel less anxious when the class size is small or I have many close friends. My close friends are well aware of my level of English, so they don't mind if I use a little Japanese. We can help each other and can do pair/group work without worrying about making mistakes. (1) \#34; 2) F; 3) 3; 4) 24; 5) Spanish)

Comfortable

classroom

environment

I get anxious when the teacher joins the group work or when the teacher asks me to answer, so I want to be left alone. (1) \#36; 2) F; 3) 2; 4) 25; 5) Chinese)

I want to participate in the activities, but I have trouble understanding if the teacher uses only English. I can understand better when the teacher explains difficult words and grammar in Japanese. (1) \#25;2) F; 3) 1; 4) 22; 5) Korean)

Good English speakers are unaware of how much they are hurting bad English speakers. When I don't understand what others have said, or when I can't express what I want to say, I worry about what to do and

Peer pressure want to use a little L1. When I talk with friends who have equal English ability, I can have a relaxed conversation without getting frustrated because they don't expect me to speak well. (1) \#24;2) F; 3) 2; 4) 22; 5) Indonesian)

Communication classes should be divided according to English proficiency in speaking and students should be placed in an appropriate level of class. Students' L1 use might decrease if they had a partner at a similar level because they would both use understandable English with each other. (1) \#37; 2) F; 3) 3; 4) 25; 5) Korean)

If I am put in a class with a much higher level of English than my own, I would feel bad for not living up to Effective my partner's expectations. If my partner is frustrated, I will feel anxious and my performance will be even class type worse. Therefore, I would like to participate in a class with a slightly higher speaking ability than mine. (1) \#27; 2) F; 3) 3; 4) 22; 5) Korean)

I would like to experience more joint classes with exchange students (45 minutes of English lessons and 45 minutes of Japanese). We were very happy to be able to teach each other a language. If I have friends who are native English speakers, I will be more interested in speaking English and I will be better at doing so. I think this is a good way to learn a language. (1) \#30; 2) F; 3) 2; 4) 23; 4) 23; 5) Thai)

Note. 1) I.D.\#; 2) Gender (M/F); 3) Academic year (1 = freshman, 2 = sophomore, 3 = junior, $4=$ senior); 4) Anxiety levels from eight (lowest) to 25 (highest); 5) Language major

\section{Discussion}

It is important that teachers understand students' needs, some of which the teachers may be unaware while teaching them. Students with high levels of anxiety preferred to perform group/pair activities in small groups/pairs of close friends, which increased peer interactions. With regard to the other reasons, close friends have a good understanding of each other's level of English proficiency and are not afraid of making mistakes; they can also tolerate each other's occasional use of Japanese and help each other. This is supported by MacIntyre et al.'s (1998) assertion that inter-speaker relationships, including power relations, the level of intimacy, and social distance, are important elements in second/foreign language (L2/FL) communication. In terms of language learning, it has also been reported that other learners play an important role (Thomas \& Rose, 2019), and that peer interactions help to improve TL proficiency (Chen, 2018; Crawford, McDonough, \& Brun-Mercer, 2019). Students need to help each other more often (Dörnyei, 1997) and to exchange ideas with their classmates (Murphey et al., 2014). Therefore, it is important to create a friendly, threat-free classroom atmosphere in which students do not compare themselves to or compete with other students (Liu \& Jackson, 2008; Piechurska-Kuciel, 2011). Furthermore, in the present research, it was found that what highly anxious students wanted from their teachers was not to interfere during pair/group work; furthermore, teachers should not intervene or ask students to answer in front of the entire class, and teachers should explain difficult aspects and complicated grammar in the L1 if necessary.

During pair work, if one partner is extremely proficient in English and the other partner has a very low level of proficiency, this can have a negative impact on both partners. As examples from this study, students who spoke English well hurt the feelings of students who spoke English poorly by looking down on them. On the other hand, students who were poor at speaking could see that they were frustrating their partners, which made them feel overwhelmed and their performances became even worse. Therefore, when assigning classes and pairs, it appears to be important to consider the students' levels of English proficiency particularly if high-level students are 
unwilling to help their partners, so that students with superior language ability are not prevented from practicing speaking by students with limited language ability, and in order for students who cannot speak English fluently not to be made to feel miserable. In such situations, if students with similar levels are paired, they can perform the assigned activities in a relaxed manner.

With regard to dividing classes to ensure proper pairing, many students in this study proposed that communication classes should consist of students with the same level of proficiency in speaking. This is in line with Wilkinson's (2012) suggestion that it is better to administer a speaking test than it is to use the Test of English for International Communication (TOEIC) that does not have a speaking component when streaming students into courses that focus primarily on speaking. In fact, the poor speakers were making every effort possible and were only using the L1 as a last resort to avoid communication problems, but the students who were proficient in speaking did not appear to understand this. Therefore, this type of class division may be necessary for the sakes of both groups of students. On the other hand, one teacher and a few of the students suggested mixed-level classes based on both speaking ability and on TOEIC test scores (listening and reading). When classrooms consist only of students with low English proficiency, conversations tend to take place in the L1 rather than in English because of the students' limited English proficiency. Therefore, these participants argued that students with low speaking ability needed role models and help from advanced-level students. There does appear to be a rationale for this idea. Furthermore, the suggestion to have a joint class with exchange students as a new type of class is interesting if teachers can arrange this. Making friends with native TL speakers may be beneficial for increasing the incentive to study the TL and for preventing students from becoming bored in class.

With regard to the pedagogical implications, increased pair and group work will encourage interactions among classmates and will help them to get to know each other; this should be encouraged because, once the students know each other well, they will be able to help each other and create a comfortable classroom environment. Teachers should not intervene excessively in the students' tasks and should allow them to work independently, but the teachers should also help and support the students when they are experiencing difficulty. It is important for teachers to always try to understand the needs and feelings of their students and to respond them accordingly.

In terms of limitations, the students insisted on some solutions that teachers were powerless to implement; for example, the number of students in a class or the division of levels in a class are not factors that a teacher can control. Furthermore, combined classes with international students would not be possible unless the university has many foreign students who are learning Japanese. In other words, the causes of students' anxiety revealed in this research might have included problems of which the teachers were well aware, but over which they might have little or no control. Therefore, the findings may not be generalizable to some other EFL contexts.

\section{Conclusions}

When comparing the results from the interviews with the highly anxious students to the results from the interviews with the teachers (Inada, 2021), this research revealed some causes of the students' anxiety of which teachers might not have been aware (or might well have been aware but had little or no control over them) and presented solutions suggested by the students. It should be emphasized that mismatched partners were more likely to compare their proficiency levels, which may have resulted in more proficient students feeling as though they were wasting time on speaking practice and less proficient students feeling more anxious. It is necessary to decrease competition and peer pressure and to make classrooms environments in which students help each other instead of comparing themselves and competing. To achieve this, it seems appropriate to consider class size, class division, and the creation of a new type of class. It is hoped that the experiences of students with high levels of speaking anxiety in communicative EFL classrooms will encourage teachers to recognize and implement what the students need.

\section{References}

Ahmad, B. H., \& Jusoff, K. (2009). Teachers' code-switching in classroom instructions for low English proficient learners. English Language Teaching, 2(2), 49-55. https://doi.org/10.5539/elt.v2n2p49

Bailey, K. M. (1983). Competitiveness and anxiety in adult second language learning: Looking at and through the diary studies. Rowley, MA: Newbury House.

Botes, E., Dewaele, J-M., \& Greiff, S. (2020). The Foreign Language Classroom Anxiety Scale and Academic Achievement: An Overview of the Prevailing Literature and a Meta-Analysis. Journal for the Psychology of Language Learning, 2, 26-56. https://doi.org/10.52598/jpl1/2/1/3

Chen, W. (2018). Patterns of pair interaction in communicative tasks: The transition process and effect on L2 teaching and learning. ELT Journal, 72(4), 425-434. https://doi.org/10.1093/elt/ccy015 
Crawford, W. J., McDonough, K., \& Brun-Mercer, N. (2019). Identifying linguistic markers of collaboration in second language peer interaction: A lexico-grammatical approach. TESOL Quarterly, 53(1), 180-207. https://doi.org/10.1002/tesq.477

Dolean, D. D. (2016). The effects of teaching songs during foreign language classes on students' foreign language anxiety. Language Teaching Research, 20(5), 638-653. https://doi.org/10.1177/1362168815606151

Dörnyei, Z. (1997). Psychological processes in cooperative language learning: Group dynamics and motivation. The Modern Language Journal, 81(4), 482-493. https://doi.org/10.1111/j.1540-4781.1997.tb05515.x

Fenyvesi, K. (2021). Emic perspective on young Danish learners' foreign language classroom anxiety. Language Teaching Research, 25(3), 1-19. https://doi.org/10.1177/13621688211001200

Gardner, R. C. (1985). Social psychology and second language learning: The role of attitudes and motivation. London, UK: Edward Arnold.

Gregersen, T., MacIntyre, P. D., \& Meza, M. D. (2014). The motion of emotion: Idiodynamic case studies of learners' foreign language anxiety. The Modern Language Journal, 98(2), 574-588. https://doi.org/10.1111/modl.12084

Horwitz, E. K. (2000). It ain't over 'til it's over: On foreign language anxiety, first language deficits, and the confounding of variables. The Modern Language Journal, 84(2), 256-259. https://doi.org/10.1111/0026-7902.00067

Horwitz, E. K., Horwitz, M. B., \& Cope, J. (1986). Foreign language classroom anxiety. The Modern Language Journal, 70(2), 125-132. https://doi.org/10.1111/j.1540-4781.1994.tb02026.x

Inada, T. (2021). Teachers' Strategies for Decreasing Students' Anxiety Levels to Improve Their Communicative Skills. English Language Teaching, 14(3), 32-41. https://doi.org/10.5539/elt.v14n3p32

Jordan, G., \& Gray, H. (2019). We need to talk about coursebooks. ELT Journal, 73(4), 438-446. https://doi.org/10.1093/elt/ccz038

Kang, S.-J. (2005). Dynamic emergence of situational willingness to communicate in a second language. System, 33, 277-292. https://doi.org/10.1016/j.system.2004.10.004

Kim, E. Y. (2011). Using translation exercises in the communicative EFL writing classroom. ELT Journal, 65(2), 154-160. https://doi.org/10.1093/elt/ccq039

Levine, G. S. (2003). Student and instructor beliefs and attitudes about target language use, first language use, and anxiety: Report of a questionnaire study. The Modern Language Journal, 87(3), 343-364. https://doi.org/10.1111/1540-4781.00194

Liu, M. (2017). Adult Chinese as a second language learners' willingness to communicate in Chinese: Effects of cultural, affective, and linguistic variables. Psychological Reports, 120(3), 423-442. https://doi.org/10.1177/0033294117692808

Liu, M., \& Jackson, J. (2008). An exploration of Chinese EFL learners' unwillingness to communicate and foreign language anxiety. The Modern language Journal, 92(1), 71-86. https://doi.org/10.1111/j.1540-4781.2008.00687.x

MacIntyre, P. D., Clement, R., Dörnyei, Z., \& Noels, K. A. (1998). Conceptualizing willingness to communicate in a L2: A situational model of L2 confidence and affiliation. The Modern Language Journal, 82(4), 545-562. https://doi.org/10.1111/j.1540-4781.1998.tb05543.x

MacIntyre, P. D., Noels, K. A., \& Clement, R. (1997). Biases in self-ratings of second language proficiency: The role of language anxiety. Language Learning, 47(2), 265-287. https://doi.org/10.1111/0023-8333.81997008

MacIntyre, P. D., \& Doucette, J. (2010). Willingness to communicate and action control. System, 38(2), 161-171. https://doi.org/10.1016/j.system.2009.12.013

Mackey, A., \& Gass, S. M. (2008). Second Language Research: Methodology and Design. NY, USA: Routledge.

Murphey, T., Falout, J., Fukuda, T., \& Fukada, Y. (2014). Socio-dynamic motivating through idealizing classmates. System, 45, 242-253. https://doi.org/10.1016/j.system.2014.06.004

Najeeb, S. S. R. (2013). Learner autonomy in language learning. Procedia-Social Behavioral Sciences, 70, 1238-1242. https://doi.org/10.1016/j.sbspro.2013.01.183 
Pan, C., \& Zhang, X. (2021). A longitudinal study of foreign language anxiety and enjoyment. Language Teaching Research, 25(2), 1-24. https://doi.org/10.1177/1362168821993341

Phillips, E. M. (1992). The effects of language anxiety on students' oral test performance and attitudes. The Modern Language Journal, 76(1), 14-26. https://doi.org/10.1111/j.1540-4781.1992.tb02573.x

Piechurska-Kuciel, E. (2011). Perceived teacher support and language anxiety in Polish secondary school EFL learners. Studies in Second Language Learning and Teaching, 1(1), 83-100. https://doi.org/10.14746/ssllt.2011.1.1.5

Rivers, D. J. (2011). Politics without pedagogy: Questioning linguistic exclusion. ELT Journal, 65(2), 103-113. https://doi.org/10.1093/elt/ccq044

Saito, Y., \& Samimy, K. K. (1996). Foreign language anxiety and language performance: A study of learner anxiety in beginning, intermediate, and advanced-level college students of Japanese. Foreign Language Annals, 29(2), 239-249. https://doi.org/10.1111/j.1944-9720.1996.tb02330.x

Thomas, N., \& Rose, H. (2019). Do language learning strategies need to be self-directed? Disentangling strategies from self-regulated learning. TESOL Quarterly, 53(1), 248-257. https://doi.org/10.2307/3586262

Wilkinson, D. (2012). Student-centered activities in mixed-level classes. In A. Stewart \& N. Sonda (Eds.), Proceedings of JALT Conference, 2011 (pp. 625-635). Tokyo: JALT.

Yan, J. X., \& Horwitz, E. K. (2008). Learners' perceptions of how anxiety interacts with personal and instructional factors to influence their achievement in English: A qualitative analysis of EFL learners in China. Language Learning, 58(1), 151-183. https://doi.org/10.1111/j.1467-9922.2007.00437.x

Young, D. J. (1990). An investigation of students' perspectives on anxiety and speaking. Foreign Language Annals, 23(6), 539-567. https://doi.org/10.1111/j.1944-9720.1990.tb00424.x

Zhang, X. (2019). Foreign language anxiety and foreign language performance: A meta analysis. The Modern Language Journal, 103(4), 763-781. https://doi.org/10.1111/modl.12590 


\section{Appendix}

A five-point Likert Scale Questionnaire of Foreign Language Classroom Anxiety (FLCA)

A1. It embarrasses me to volunteer answers in English class.

A2. I do not feel confident when I speak in English class.

A3. I always feel that the other students are speaking English better than I do.

A4. I get nervous and confused when I am speaking in English class.

A5. I do care what other students think of me when I speak English.

The scale ranges from strongly disagree $=1$, disagree $=2$, neutral $=3$, agree $=4$, strongly agree $=5$, and the lower the total score, the lower the FLCA level

\section{Copyrights}

Copyright for this article is retained by the author(s), with first publication rights granted to the journal.

This is an open-access article distributed under the terms and conditions of the Creative Commons Attribution license (http://creativecommons.org/licenses/by/4.0/). 